\title{
Phytoprotection
}

\section{Policy and Regulations for Registration of Microbial Organisms in Denmark}

\author{
Bettina Helle Jensen
}

Volume 79, numéro 4, 1998

OECD Workshop - Sustainable Pest Management, Safe Utilization of New Organisms in Biological Control. Montréal, Québec, Canada. September 27-30, 1998.

Atelier de l'OCDE - Gestion durable des ennemis des cultures, Utilisation sécuritaire de nouveaux organismes de lutte biologique. Montréal, Québec, Canada. 27-30 Septembre 1998.

URI : https://id.erudit.org/iderudit/706148ar

DOI : https://doi.org/10.7202/706148ar

Aller au sommaire du numéro

\section{Éditeur(s)}

Société de protection des plantes du Québec (SPPQ)l

\section{ISSN}

0031-9511 (imprimé)

1710-1603 (numérique)

Découvrir la revue

Citer cet article

Jensen, B. H. (1998). Policy and Regulations for Registration of Microbial Organisms in Denmark. Phytoprotection, 79(4), 5-9.

https://doi.org/10.7202/706148ar
Résumé de l'article

In Denmark several factors like the national pesticide action plan, ethical questions, national research strategy, increasing share of organic farming and fees are affecting the policy regarding regulatory agencies approach for products supporting sustainable pest management.

The use of microbial pesticides in Denmark are limited, with the relatively largest share used in the greenhouse sector.

Approval of a product not sold in Denmark before July 26, 1993 consists of two parts: An EU approval of the active micro-organism, and a national approval of the product containing the active micro-organism. An EU approval of an active micro-organism is only granted if the active micro-organism is included in Annex I of the directive of authorized active organisms. As a main principle, an active micro-organism shall be entered on the list of authorized active organisms before the Danish EPA may grant an approval for sale or import of products containing active micro-organisms. Until now five new organisms have been recommended for EU approval and inclusion in Annex I of the Directive, but so far none have been included.

For products sold in Denmark before July 26, 1993 a transitional scheme specified in the Order is applied. Under this procedure application for approval of such products should be submitted to the Danish EPA before July 26, 1994 if the products were intended for sale in Denmark after this date. The application is considered at a national level only by the Danish EPA. The Danish EPA has received applications concerning nine different active micro-organisms.

Both GMO's and biocides are covered by specifie legislation. If the GMO's are also pesticides, they must also comply with the Danish pesticides legislation. As no transgenic microbial pesticides or microbial biocides have yet been registered in Denmark, there is no legal practice on this issue.
Ce document est protégé par la loi sur le droit d'auteur. L’utilisation des services d'Érudit (y compris la reproduction) est assujettie à sa politique d'utilisation que vous pouvez consulter en ligne.

https://apropos.erudit.org/fr/usagers/politique-dutilisation/ 


\title{
Policy and Regulations for Registration of Microbial Organisms in Denmark
}

\author{
Bettina Jensen
}

Ministry of environment and Energy, Danish Environmental Protection Agency, Division of Agriculture and Biotechnology, Copenhagen, Denmark

\section{ABSTRACT}

In Denmark several factors like the national pesticide action plan, ethical questions, national research strategy, increasing share of organic farming and fees are affecting the policy regarding regulatory agencies approach for products supporting sustainable pest management.

The use of microbial pesticides in Denmark are limited, with the relatively largest share used in the greenhouse sector.

Approval of a product not sold in Denmark before July 26, 1993 consists of two parts: An EU approval of the active micro-organism, and a national approval of the product containing the active micro-organism. An EU approval of an active micro-organism is only granted if the active micro-organism is included in Annex I of the directive of authorized active organisms. As a main principle, an active micro-organism shall be entered on the list of authorized active organisms before the Danish EPA may grant an approval for sale or import of products containing active micro-organisms. Until now five new organisms have been recommended for EU approval and inclusion in Annex I of the Directive, but so far none have been included.

For products sold in Denmark before July 26, 1993 a transitional scheme specified in the Order is applied. Under this procedure application for approval of such products should be submitted to the Danish EPA before July 26, 1994 if the products were intended for sale in Denmark after this date. The application is considered at a national level only by the Danish EPA. The Danish EPA has received applications concerning nine different active micro-organisms.

Both GMO's and biocides are covered by specific legislation. If the GMO's are also pesticides, they must also comply with the Danish pesticides legislation. As no transgenic microbial pesticides or microbial biocides have yet been registered in Denmark, there is no legal practice on this issue.

\section{INTRODUCTION}

In view of the European policies on agricultural pest management e.g. to reduce emissions and use of chemical pesticides and to be less dependent on the use of chemical pesticides, and also, in view of rapid biotechnological developments, it may be expected that in the near future the use of microbial pesticides will increase. It is difficult to predict, but as research and development of biological pest management is still in an early phase, especially outside greenhouses, the implementation of integrated pest management (IPM) (e.g. by biological and chemical means) could be seen as a major goal, rather than changing radically from chemical to biological pest management. This means that on a short term, risk assessment of substances to be 
used in agricultural pest management may comprise both a microbial and a chemical component.

\section{FACTORS AFFECTING THE USE OF MICROBIAL PESTICIDES}

Microbial pesticides have their most important strength and weakness in what is named specificity. In terms of ecology, specificity is a strength, but in terms of economy, it is a weakness: economic considerations are requiring a broad target range and thus a lower degree of specifivity.

In the years to come, where the market is maturing and competition is sharpening, this contradiction will demand a careful balance between economic and ecological considerations. Too much focus on economy might have the impact that user and consumer acceptance and thereby market shares are lost.

Research breakthroughs can in the years to come contribute to solving some of the constraints which, today, narrow the use of microbial pesticides. It is problems such as low efficacy of the microbial products, narrow host range, low persistence and development of resistance. New and modern biomolecular methods are expected to contribute to solving these problems and to give microbial pesticides and increased market share.

Research breakthroughs in competing fields might have a considerable negative impact as well. Especially new chemical products and transgenic plants should be expected as important competitors to microbial pesticides in coming years.

Also politics and legislation relations have played a major role. In Denmark and in the EU, legislation governing new product approvals has now been in force for five years in the field of microbial pesticides.

Product registration and approval on the one hand often might lead to the concern that small companies will not be able to register new products, and that small scale product will be excluded from the market. This concern can be even more pronounced if new biomolecular methods are used in problem solving, because the use of these methods will result in more extensive registration.

On the other hand, product registration and approval might lead to strong documentation of the relative benefits of microbial pesticides compared to chemical pesticides with regard to the environmental and health impact on man, animals, plants and beneficial insects. This documentation may become a valuable tool in marketing the products, especially together with proper labelling, where consumer and user acceptance is a condition for market penetration.

User education might also be an important factor influencing the market penetration of microbial pesticides. IPM systems and similar quality-oriented production systems demand education and qualified training, and gives room for introduction of a variety of microbial products. Expansion of IPM will also lead to an increased market for microbial products together with transgenic plants and other new chemical and biochemical pesticides.

Microbial pesticides will in the years to come increase their market shares. Several factors can and will influence this development both positively and negatively, but it should be anticipated that the net result will be stable growth.

\section{TENDENCIES IN DENMARK}

The discussion on sustainable production/agriculture naturally implies a number of ethical questions. The intensive production methods used in modern agriculture, e.g. structural development, establishment of large animal farm units, especially pig farms, the use of growth-promoting products and constant monocultural production of e.g. wheat, are topics of intense public interest. The debate in Denmark is greatly influenced by ethical questions, and 
the result has to be new ways of development in agricultural production.

In Denmark, $4 \%$ of the agricultural area is cultured organically, and this figure is expected to increase in the coming years. In Denmark, the organic farmers have raised to a level where they are respected among the consumers and their colleagues in traditional agriculture. There is no doubt that the organic farmers have reached that level by taking ethical questions into consideration. The fact is that the organic farmers have done what every farmer dream of. They have managed to make the consumers accept to pay $20 \%$ extra for products which are, physically, similar to products produced by conventional methods.

The use of chemical pesticides must not disturb our water supply, and monitoring is therefore still important to ensure that the relevant chemical pesticides are gradually either forbidden or phased out. The overall use of chemical pesticides in Denmark has decreased, but not enough compared to the objectives of the pesticide action plan, and the reduction potential is far from being reached.

It is not unrealistic to believe that biotechnology, especially the development of transgenic plants and pesticide resistant plants, are important factors in solving the problems of reducing the pesticide consumption.

\section{GOVERNMENTAL STRATEGIES IN DENMARK TO REACH SUSTAINABLE AGRICULTURAL PRODUCTION}

In the spring of 1997, the Danish Parliament passed a resolution requesting the Danish Government to appoint a committee of independent experts, to assess, before the end of 1998, the overall consequences of phasin out chemical pesticides in agriculture, and to have a thorough discussion of alternative plant protection options. The results of the committee will be included in the revised pesticide action plan.
The committee counts representatives from research institutions, the agricultural industry, the NGO's, consumer organisations, the food and agrochemical industry, labour unions, and the relevant ministries.

\section{RESEARCH IN DENMARK}

The general strategy in Denmark is to support the use microbial pesticides, and several studies are sponsored by the State. Furthermore, the issue included in the Government Strategy on Biotechnology. The following research studies are fully or partly financed by the Danish EPA:

- Possible Bacillus cereus-like effects of the use of Bacillus thuringiensis as an insecticide (1998-2000)

- The production of secondary metabolites from micro-organisms. Part one was a literature study and in part two Trichoderma harzianum was studied as an example of an organism pruducing secondary metabolites (in press)

- Environmental effects of horizontal gene transfer among bacteria in soil (1995-1998)

- Effects of microbial insecticides on human health when used in greenhouses, especially allergenic effect (1995-2000)

- Effect of Bacillus thuringiensis on Pieris brassicae (in press)

- Microbial control of aphids (in press)

- Use of micro-organisms as seed fungicides (in press)

- Microbial cell wall preparations for use in plant protection (1997-2000)

\section{STATE OF THE ART IN DENMARK}

The use of microbial pesticides in Denmark is limited, with the relatively largest share used in the greenhouse sector. Microbial pesticides are used neither in freeland agricultural production nor in the fruit and vegetable sector, 
since the pests most often found in Danish agriculture cannot be controlled by the products which are available on the market at present, while pests for which efficient microbial products do exist are of limited importance for freeland production.

On July 15, 1993, the EC Agricultural Council adopted the Directive concerning the Placing of Plant Protection Products on the Market(Directive 91/414/ EEC), introducing a Community procedure for the approval of plant protection products, including microbial products. Under the Directive, a plant protection product can only be authorised if it has no unacceptable impact on plants or the environment and no harmful effects on human or animal health or on groundwater. In Denmark, the Directive is implemented by Statutory Order on Pesticides, and microbial pesticides shall before sale, import or use, be authorised by the Danish EPA.

Approval of a product not sold in Denmark before July 26, 1993, consists of two parts: An EU approval of the active micro-organism, and a national approval of the product containing the active micro-organism. An EU approval of an active micro-organism is only granted if the active micro-organism is included in Annex I of the Directive of authorised active organisms. As a main principle, an active micro-organism shall be entered on the list of authorised active organisms before the Danish EPA may grant an approval for sale or import of products containing active micro-organisms. Until now, five new organisms have been recommended for EU approval and inclusion in Annex I of the Directive, but so far none have been included.

For products sold in Denmark before July 26, 1993, a transitional scheme specified in the Order is applied. Under this procedure, application for approval of such products should be submitted to the Danish EPA before July 26, 1994 , if the products were intended for sale in Denmark after this date. The application is considered at a national level only by the Danish EPA. The Danish EPA has received applications concerning nine different active microorganisms.

Fees are not paid for applications for registration of a microbial or chemical pesticide, and the fees paid for microbial pesticides after approval are very low (3\% of the sale) compared to both the chemical herbicides and fungicides ( $13 \%$ of the sale) and the chemical insecticides $(37 \%$ of the sale).

Genetically modified (micro)organisms are covered by specific legislation. Therefore, transgenic microbial pesticides will be registered in accordance with the specific rules. However, as they are also pesticides, they must also comply with the Danish pesticides legislation. As no transgenic microbial pesticides have yet been registered in Denmark, there is no legal practice on this issue.

\section{IDENTIFYING ISSUES AND NEEDS FOR RESEARCH IN OECD COUNTRIES, TO ENSURE SUSTAINABILITY OF AGRICULTURAL SYSTEMS USING NEW ORGANISMS IN BIOLOGICAL CONTROL}

Micro-biological pesticides are often promoted as less environmentally hazardous alternatives to chemical pesticides. The use of microbial pesticides therefore is a natural and important element of sustainable agriculture. But still a number of aspects need further investigation, especially concerning risk/ impact on human health and ecological risk connected to the use of microbial pesticides.

At the national level, research is needed especially on the following subjects:

- Residues, after use of the microbial pesticide and spreading in the environment

- When and why do the micro-organisms produce toxic metabolites, and their effect on mammals 
- The natural occurrence and activity in the environment of the microbial pesticides

- Development of test systems to measure environmental effects and to identify the organisms in the environment

- Setting up of soil quality criteria to measure the environmental effect of both chemical and micro-biological pesticides.

At international level it is of great importance to establish:

- uniform principles for the evaluation of plant protection products

- a shorter evaluation schedule for the "old" active organisms
- electronic evaluation procedure common (EU and OECD) register including both the old and the new organisms and their data

\section{THREE QUESTIONS TO}

\section{FACILITATE THE}

\section{DISCUSSION}

- Does sustainable production include a total phase-out of chemical pesticides?

- Does sustainable production also include $100 \%$ organic farming?

- Does sustainable production include the use of modern biotechnology (genetic engineering)? 